\title{
The Rights-based Approach to Development: Potential for Change or More of the Same?
}

\section{Dzodzi Tsikata}

\section{Introduction}

The adoption of Rights-based Approaches (RBAs) by the UN and its agencies, many bilateral development agencies and international development non-governmental organisations (NGOs) has allowed human rights language to enter the world of development as a welcome and legitimate friend. Not surprisingly, much timber and ink have been used debating the merits and demerits of this development. Sceptical voices are arguing that the development industry has simply taken the high minded concerns of human rights instruments and moulded them to its own purposes, and therefore not much is likely to change in policies and programmes (Uvin 2002).

While there appears to be much more endorsement of the RBA than disagreements with it, the critique is striking in how much it sounds like feminists' anxieties about the use of gender and gender mainstreaming in development practice. As we discussed extensively at the conference on which this IDS Bulletin is based, since gender issues became part of development debates in the 1970s, different approaches have become dominant and waned under the critical gaze of feminists within and outside the development industry. How the development industry has taken up and digested the analyses and prescriptions of feminists has neither been predictable nor always happy in outcomes. Questions arise about why a section of the women's movement is rejoicing about this widespread "adoption" of the RBA. Are they right to hail the progress of the RBA as a happy convergence of the women's movement with the development industry? Are they rushing to judgement or is there something new and interesting happening? What, if anything, has changed and what does it mean for the old ways of doing development in general and gender and development in particular?

\section{RBA: definitions and doubts}

There is no one RBA. There is, however, common thinking on its basic elements. These include an express linkage to rights, greater accountability on the part of states and international actors, a greater stress on empowerment, participation and nondiscrimination and attention to vulnerable groups (OHCHR 2004). The injection of rights into development discourse and programming is a positive development and indeed has always been part of the strategy of certain NGOs. This is because rights are very important in contexts which privilege functionalist and instrumentalist gender equality discourses across the government civil society divide. Much damage has been done by the promotion of gender equality or equity on grounds such as national development, poverty reduction, better population indicators, basically everything and everyone, except for women themselves as citizens with rights.

Disagreements between proponents and critics of the RBA have been less about the importance of human rights and more about whether aims such as accountability, participation and peoplecentredness, which have long been fought for in development circles are now realisable simply because of the adoption of the RBA. In other words, do the human rights (HR) instruments on which the RBAs are based, and the RBAs themselves, have the ability to transform development practice? A related question is whether the stated advantages 
of RBAs are particular to these approaches. After all, several pre-RBA approaches have in their time claimed similar advantages.

Scepticism about the RBA arises from a feeling that little more than the language of development has changed. Within the RBA framework, economic liberalisation is not up for discussion; whatever human rights are on the table have to be realised within its framework (Piron 2002; Uvin 2002). Even with the dressing-up of the Millennium Development Goals (MDGs), programmes such as Heavily Indebted Poor Countries (HIPC) and the Poverty Reduction Strategy Papers (PRSPs) will remain essentially liberalisation programmes with poverty alleviation added on. Given the history of donor fad-ism, it is anyone's guess how long it will take for a new development approach to take over the "holy grail" status of the RBAs. This can happen quite easily because of the continuing confusion about what the RBAs are and are not, and the fact that what is being claimed for them has been advocated within the development circles for decades.

Touted as ensuring grassroots participation, RBAs are now being pushed by powerful players onto governments, civil society organisations and communities. The neo-liberal consensus, occurring as it is at the height of the war on terror and the erosion of political and civil rights and certain women's rights in America, does not create auspicious circumstances for proceeding in a way which realises the hopes that the feminist human rights constituency is investing in the RBAs - unless they share the Trojan Horse analysis of the RBA which suggests that once it is adopted, it implies obligations which citizens can then demand implementation of, and through that progressively change the landscape (Uvin 2002; Slim 2002). Given that the site of development policy-making has changed from the state to the international arena, the focus of the RBA on national actors citizens and governments excludes the corporate sector, foreign governments and the International Financial Institutions (IFIs) from scrutiny. Some may note the irony that while RBAs are a response by the UN, northern governments and the IFIs to demands by countries from the South that the right to development (RTD) be taken seriously, much of its provisions are directed at Southern governments. The lukewarm reaction of the very governments from the global South who championed the RTD within the context of a New International Economic
Order (NIEO) has been attributed to fears that the RBAs represent another round of donor conditionalities which continue in the tradition of protecting donors and the IFIs from having to take equal responsibility for policy errors.

Debates about the link between the RBAs and the UN Declaration on the Right to Development and the enforceability of certain HR instruments and rights under the RBA point to the legal paraphernalia needed to work within a rights paradigm. This contradicts the idea that the powerless would take centre stage. After years of legal literacy directed at poor African women, very few of them use lawyers and the courts to address violations of their rights. This is likely to deepen the technicisation and depoliticisation of gender and development work, something many have justly criticised. Moreover, are the expectations of legal institutions and the legal and para-legal professions justified given their poor record as champions of the rights of the poor and social groups such as women?

The complicated relationship between women, the state and the law makes rights at best a contested arena. The inadequacy of rights discourses to address human rights abuses against women taking place in the private sphere around sexuality, marriage, reproduction, inheritance and the custody of children is an issue (Carnegie Council on Ethics and International Affairs 2000). The inability of rights analysis to account for the nuances of gender and other social relations is another problem. It is also doubtful if rights are the best analytical tools for understanding the challenges of globalisation, militarism, the rise of the transnationals, and the impacts of neo-liberal policies, class, gender, race, kinship and other social relations. Does the rights language help us to understand the world trading system, or even marriage and intra-household relations? Where did the wealth of analysis about the state, the law and rights generated over the years go in all the optimism about rights-based approaches?

All these issues should concern us because they raise fundamental questions about the rights-based development paradigm. Given that RBAs are said to have special relevance for gender and development and that what women failed to achieve under other gender and development approaches would become possible under RBAs, it becomes even more critical to tackle their gender dimensions. I now turn to these issues. 


\section{RBA and gender}

If RBAs raise so many questions, why are women's human rights activists so enthusiastic about them? Two arguments have been made for why the rightsbased approaches are good for women. One is that the norm of gender equality is central to RBAs, not "as an add-on" but because equality and nondiscrimination are central to human rights and are included in most conventions. Secondly, since RBAs focus on the most marginalised in society, women are a natural constituency (AWID 2002). These are good reasons to pay attention to human rights, but they do not translate into RBAs being superior to other gender and development approaches.

Human rights activists, who are no novices to struggles within the mainstream human rights movement, have a well-deserved reputation for fighting long and hard and have been successful in injecting women's rights into the discourse of human rights. However, with a few exceptions, their contribution to gender and development advocacy has been less significant. Many of their allies in African countries are human rights lawyers' organisations who have tended to work with specific women's rights issues such as violence against women, discrimination under customary law rules of marriage and inheritance and more recently women's land rights. They are less known for their work on the broader issues of the direction and orientation of development policies although a few have been active in research on the impacts of structural adjustment on women workers. Thus, in spite of a critique of globalisation and its impacts on poor countries, HR feminism continues to be dominated by forces not particularly worried about the development paradigm and its implications for women.

Over the course of the 1990s, the growing confidence and optimism of certain sections of the women's human rights movement and their growing stature in the UN system became apparent in their ability to influence conference outcomes from Vienna to Cairo to Copenhagen to Beijing. That optimism of the 1990s has been reduced quite rapidly in the ten years since Beijing. The war of attrition between women's groups on the one hand and powerful conservative governments from the USA, certain parts of the Middle East and Latin America and the Vatican on the other hand, has taken its toll. Women's groups, wary of the possibility of the erosion of their hard won gains under the Beijing Platform for Action, are proposing that the Platform document not be open to review at this time. Instead, they are proposing a review of implementation and a discussion of how to improve implementation. This is not because the Platform does not have provisions they would like to change but rather that the geopolitical situation in the world today and the assaults on women's rights the world over do not give grounds for optimism. As it is in this same context that RBAs are being adopted, the grounds for optimism are not very clear.

That dissemination of the RBA is UN led, means that it comes with the UN's baggage. In relation to women's rights, the demobilisational effects of the UN's uptake of the gender equality agenda of second-wave feminism has gone hand-in-hand with the greater visibility and legitimacy it has given to these issues at the national and international levels. The UN continues to be an important player, one of the few progressive voices in discussions about development and women's rights. Yet its current political weakness and its desperate alliances with transnational corporations and powerful governments to deliver some crumbs to the poor make it an unreliable ally in the fight for gender equality and development.

\section{What challenges are posed for feminists by the RBA?}

The main challenge the RBA poses is that it represents another instalment of contestation within gender and development. This is not helped by the multiplicity of RBA approaches and confusion about what they represent. The RBA has been touted as representing a convergence of two strands of feminism - the women's human rights organisations and those working from a gender and development perspective. Each has had distinct terminologies, different experts, specialised methodologies, separated agencies and targeted different institutional actors. Kerr (2001) argues that this divide is now converging on issues related to globalisation, recognising a link between laws and institutions and the outcomes of development schemes and programmes.

This convergence, if it is real, will be a fragile one in the light of critiques of the RBA, especially around issues of globalisation and gender equality. Thus there could be an even greater danger of 
fragmentation in the international movements. The array of forces on the different sides of the RBA divide - Northern governments and their development agencies, the UN and Northern NGOs for the RBA and Southern governments and certain Southern NGOs and other civil society organisations who are sceptical about the RBA - makes fragmentation an even greater danger. It is time to debate more fully what the RBA is about and what it represents, and this time, voices from developing countries need to take the lead. While there is not one position emerging in the developing world, and certain NGOs have already began to vote for the RBA, such an airing will be most beneficial for civil society groups and governments in the developing world. The international women's movement should champion this debate for its own good.

\section{References}

AWID, 2002, 'A rights-based approach to development', briefing paper, Toronto: Association for Women's Rights in Development (AWID)

Carnegie Council on Ethics and International Affairs, 2000, 'Silence breaking: the women's dimension of the human rights box', Human Rights Dialogue, Series 2 No 3, Summer

Kerr, J., 2001, 'International trends in gender equality work', discussion paper for the Gender Review Workshop, November, Den Haag: Nederlandse Organisatie voor Internationale Bijstand (NOVIB)

OHCHR, 2004, Human Rights and Poverty Reduction: A Conceptual Framework, Geneva: Office of the High Commissioner for Human Rights (OHCHR)
Without such interrogation, we may be seeing myth making in progress. At the very least, all the elements are there - claims based on high moral principles backed by selective evidence, a large army of convinced proponents, eloquent and elegant defences and even taller claims when the myth is questioned. Is the myth that the RBA will deliver gender equality and development a good or bad myth? Does it have strategic import in the sense of being a Trojan Horse or is it a prematurely celebratory myth, which gives a carte blanche for unmentionable things to be done in the name of human rights? Does the fact that a respected section of the women's movement is heavily involved in making this myth make a difference? Would the RBA help to reposition gender - and, if so, in what directions and to what ends?

Piron, L.-H., 2002, The Right to Development: A Review of the Current State of the Debate for the Department of International Development, London: Overseas Development Institute (ODI)

Slim, H., 2002, 'A response to Peter Uvin, making moral low ground: rights as the struggle for justice and the abolition of development', PRAXIS The Fletcher Journal of Development Studies, Vol XVII

Uvin, P., 2002, 'On high moral ground: the incorporation of human rights by the development enterprise', PRAXIS The Fletcher Journal of Development Studies, Vol XVII 